\title{
The New Article 310 of the French Civil Code for International Divorce Actions
}

Thomas E. Carbonneau

Penn State Law

Follow this and additional works at: http://elibrary.law.psu.edu/fac_works

Part of the Family Law Commons, and the Transnational Law Commons

\section{Recommended Citation}

Thomas E. Carbonneau, The New Article 310 of the French Civil Code for International Divorce Actions, 26 Am. J. Comp. L. 446 (1977).

This Article is brought to you for free and open access by the Faculty Works at Penn State Law eLibrary. It has been accepted for inclusion in Journal Articles by an authorized administrator of Penn State Law eLibrary. For more information, please contact ram6023@psu.edu. 


\title{
THE NEW ARTICLE 310 OF THE FRENCH CIVIL CODE FOR INTERNATIONAL DIVORCE ACTIONS
}

\author{
Thomas E. Carbonneau*
}

\section{INTRODUCTION}

The variety and complexity of the legal issues that can confront a French court in an international divorce action ${ }^{1}$ may best be illustrated by a description of the basic factual pattern of, and the initial arguments advanced in, some of the more typical cases:

\section{French National Spouse v. Foreign National Spouse.}

After their marriage in Marseilles, Spouse A, a French national, and Spouse B, a Spanish national, moved to Madrid. Several years later, they obtained a judicial separation from a Madrid tribunal. Although they continued to live in Madrid, they maintained residences in different parts of the city.

The year following their separation, Spouse A filed a request before the Tribunal de grande instance of Marseilles to have the Spanish separation converted to a divorce under French law. Upon receiving notice of the action, Spouse B filed a motion contesting the jurisdiction of the Marseilles court to hear the action. He also asserted that, in view of the spouses' common domicile in Madrid, Spanish rather than French law should be applied to the merits of the action. Spanish law however prohibits the granting of divorces. ${ }^{2}$

\section{French National Spouse $v$. French National Spouse re The Validity of a Prior Foreign Divorce Decree.}

Spouses C and D were French nationals; they had met and were married in Paris. Shortly afterwards, they moved to the U.S., where

* Thomas E. Carbonneau is a Jervey Fellow, Parker School of Foreign Comparative Law.

1. These actions typically involve one of three basic fact patterns: (1) spouses of mixed nationality, e.g. a French and foreign national spouse; (2) spouses of common foreign nationality who are domiciled in France; (3) two French nationals who have either been married abroad or who are currently domiciled in a foreign country. See also text infra, at $n$. 2 to 6 . For a general description of the legal issues associated with international divorce actions, see Breton \& Hébraud, Divorce $\$$ 1771-1835, in 3 Dalligny, Ripert \& Verge (eds.), Dalloz Encyclopédié Juridique Répertoire de Droit Civil 101, 232-38 (1953); Divorce $\$ \S 382-400$, in 2 Dalligny, Segogne \& Verge (eds.), Dalloz Nouveau Répertoire de Droit 113, 142-43 (2d ed. 1963) [unsigned article] (see also Mise à Jour 649, § 621 [1977]).

2. Spanish or, until recently, Italian nationals domiciled in France quite frequently brought divorce actions before French courts. See e.g. Vigliotti c. dame Cuttilli, 64 Rev. Crit. Dr. Int'l Priv. 241 (1975) [Trib. grde instance Bobigny 27 Nov. 1973]; Dame X . . . c. Y . . ., 2 Gaz. Pal. Sommaires at 192 (1975) [Cr. de Paris 6 e ch. 4 Jul. 1975]. These cases were decided before the new conflicts provisions came into force. 
they became resident aliens and took teaching positions in New Hampshire. Some years later, they obtained a divorce from a court in Nevada on the ground of irreconcilable differences. The court had applied Nevada law to the merits notwithstanding that then-existing French law did not recognize irreconcilable differences as a ground for divorce. Indeed, the issue of the applicability of French law had not even been raised in the proceeding.

After the divorce, $\mathrm{C}$ remained in the U.S. and $\mathrm{D}$ returned to France where she married a French national some years later. This second union was far from being felicitous; as a consequence, $D$ filed a divorce action before a Paris tribunal. Her husband however filed a motion contesting the validity of their marriage. He contended that D was still married to $\mathrm{C}$ because the Nevada divorce had no legal effect in France. ${ }^{3}$

\section{Foreign National Spouses With Immigrant Status in France.}

Spouse E, an Egyptian national, and Spouse F, a Tunisian national, were immigrant workers in France. They had been married in Tunisia and returned to their respective countries of origin every summer. After several years of marriage, $\mathrm{E}$ filed a divorce action before the Tribunal de grande instance in Lyon, asserting that the French court should apply Egyptian law in view of his nationality. $F$ however contended that, under the provisions of her national law, Tunisian law was governing; she submitted that it should be applied to the merits of the action on that basis and on the additional ground that the marriage was celebrated in her country of origin. E replied that, in the event Egyptian law was not designated as the governing law, the court should apply French law in light of the spouses' common domicile in France. ${ }^{4}$

\section{Spouses of Foreign Nationality with Domiciliary Status in France.}

$\mathrm{G}$ and $\mathrm{H}$, a Belgian couple, had been domiciled in France for two years. Both were students and intended to return to Belgium the following year when their fellowship support expired. They had been living separately for a number of months owing to marital difficulties. At the outset of the third year and during G's absence from France, $\mathrm{H}$ filed a divorce action before the Tribunal de grande instance in Paris. Although a copy of the summons had been delivered to the city hall at G's place of residence, she was not served personally with notice. The court nonetheless granted the divorce, applying French law as the governing law in light of the spouses' common domicile in France. Upon returning to France, $G$ appealed the judgment. Although she did not contest the French court's jurisdiction, she did contend that Belgian law, which is more restrictive than French law in the area of divorce, ${ }^{5}$ shculd have been applied to the merits of the action in virtue of the spouses' common Belgian nationality ${ }^{6}$

3. The facts of this hypothetical situation are similar to the Rivière case (infra at n. 20-22).

4. For a discussion of the legal principles that would apply in these circumstances, see text infra at n. 39-44.

5. Francescakis, "Le surprenant article 310 nouveau du Code civil sur le divorce international," 64 Rev. Crit. Dr. Int'l Priv. 553, 564 (1975).

6. For a discussion of the legal principles that would apply in these circumstances, see text infra at n. 48-52. 
Although disparate, the facts of these four hypothetical cases point to and are unified by two salient legal issues: one jurisdictional in nature and the other pertaining to a choice of law determination. Firstly, as a preliminary matter, the party opposing the divorce almost invariably raises a jurisdictional objection, alleging that by virtue of foreign nationality and/or domicile, the French courts lack jurisdiction to hear the matter. Secondly, in the event that the jurisdictional objection is unsuccessful, the party advances a choice of law argument, requiring the court to apply a set of choice of law rules to determine whether French or foreign law will govern the merits of the proceeding.

In an action involving a French national, the jurisdictional objection often is made to no avail. Under the provisions of the Code Civil, French courts have jurisdiction to rule upon the merits of the action simply on the basis that one of the parties is a French national:

Art. 14. The foreigner, even [one] not residing in France, can be cited before French tribunals, for the execution of obligations that he contracted in France with a French national; he can be brought before French tribunals, for obligations he contracted in a foreign country toward French nationals. ${ }^{7}$

Art. 15. A French national can be brought before French Tribunals, for obligations that he contracted in a foreign country, even with a foreigner. ${ }^{8}$

Moreover, Art. 3 Code Civil provides that French law will govern matters pertaining to the personal status of French nationals. ${ }^{9} \mathrm{Al}$ though the literal language of Article 3 would require the automatic application of French law to an international divorce action involving a French national, the courts have given that provision a reciprocal interpretation, taking it to mean that personal status actions are governed by the national law of the persons in question. ${ }^{10}$ As a consequence, Art. 3 does not resolve the choice of law issue: unless the spouses have a shared citizenship-whether. foreign or French-factors other than nationality will determine the law governing the merits of the divorce action. ${ }^{11}$ In order to deal with this issue prior to the recent promulgation of the new Art. 310 Code Civil, French courts had recourse to choice of law rules which promoted the reciprocity of national law in international litigation. ${ }^{12}$ This set of judicially-created rules established a clear hierarchy between various possible sources of governing law: in reaching a determination, the courts were to choose, in order of

7. "L'étranger, même non résidant en France, pourra être cité devant les tribunaux français, pour l'exécution des obligations par lui contractées en France avec un Français; il pourra être traduit devant les tribunaux de France, pour les obligations par lui contractées en pays étranger envers des Français."

8. "Un Français pourra être traduit devant un tribunal de France, pour des obligations par lui contractées en pays étranger, même avec un étranger."

9. "Les lois concernant l'état et la capacité des personnes régissent les Français, même résidant en pays étrangers."

10. See Francescakis, supra n. $\mathbf{5}$.

11. See text infra at n. 13-26.

12. See text infra at n. 27-28. 
preference, between the common national law, the law of the common domicile, and the law of the forum. The ultimate result, of course, depended upon the particular facts of each case.

\section{The Old Choice of Law Rules}

Although its doctrine was to be abandoned by later courts, $D e$ Ferrari c. dame de Ferrari ${ }^{13}$ was the first case of major importance to deal with the choice of law problems arising in the international divorce context. There Ms. Gensoul had married an Italian national in France in 1893, and moved to Italy. In 1899, the spouses obtained a judicial separation in Genoa, the decree conforming to Italian law and based on mutual consent. Ms. Gensoul then returned to France, but in 1915, filed suit in Lyon to convert the Italian separation into a French divorce. The Lyon court assumed jurisdiction over the action pursuant to Art. 14 Code Civil, and granted the plaintiff's petition. ${ }^{14}$

On appeal, the Cour de Cassation ruled that a French national could file an action to convert a judicial separation into a divorce judgment despite the fact that the separation had been obtained in a foreign jurisdiction and that the national law of one of the spouses did not recognize divorce. The court, however, reversed the decision of the Lyon court, holding that, since the Italian separation decree was based upon mutual consent, it could not be converted into a French divorce because French law did not recognize mutual consent as a ground for divorce.

Although the court had clearly chosen French law as applicable, legal scholars and subsequent courts were uncertain about which choice of law analysis the court had adopted in order to reach that result..$^{15}$ On the one hand, the holding could be seen as reflecting a "distributive" analysis, rendering the respective national laws of the two spouses equally applicable to the merits of the action. In the instant case, since the plaintiff was a French national, French law governed the merits. ${ }^{16}$ However, the simultaneous applicability of both national laws under the distributive choice of law reasoning resulted in an anomalous situation: while, under his national law, the husband could obtain at best a separation from his spouse, his wife, by virtue of her national law, had the right, at least theoretically, of dissolving the conjugal relationship entirely. ${ }^{17}$ On the other hand, the holding could be interpreted as a "cumulative" analysis, i.e., the court designated French law as the governing law solely on the ground that one of the parties to the action was a French national. Although the cumulative analysis was consistent in outcome, it amounted to a preponderance of French over foreign law solely on the basis of French nationality. Such a rationale

13. 1 Dalloz Jur. Gen., "Cour de Cassation" at 137 (1922) [Cr. de Cassation Ch. civ $1^{\text {re }} 6$ Jul. 1922].

14. Id.

15. See e.g. 2 Battifol, Droit International Privé 70 (6th ed. 1976). For a summary of the court decisions following the Ferrari case, see id. at n. 59-3.

16. Id. at 70 .

17. Id. 
was incompatible with the need to promote reciprocity in international litigation. ${ }^{18}$ Hence to avoid this interpretation, the Ferrari holding came to be regarded as establishing a distributive choice of law rule. ${ }^{19}$ However its success as a doctrinal prouncement was short-lived. In subsequent cases, the courts abandoned the Ferrari court's distributive analysis entirely.

In Rivière c. Rivière, ${ }^{20}$ the courts began to enunciate a more uniform set of doctrinal rules by which to determine the governing law in international divorce cases. Here Lydia Roumiantzeff, a naturalized French citizen of Russian origin, had married a Russian national, Dimitri Petrov, in Paris in 1934. The parties subsequently moved to Equador where, in 1936, they obtained a divorce by mutual consent under Equadorian law. Dimitri later became a naturalized Equadorian citizen and married a Russian national in Buenos Aires in 1938. In 1939 Lydia married a French national, Robert Rivière, in Morocco. In 1945 she filed suit before a tribunal in Casablanca, seeking a divorce from her second husband. $\mathrm{He}$, in turn, filed a countersuit to have his marriage with Lydia declared null and void, alleging that, at the time of their marriage, she was still married to Petrov since the Equadorian divorce based on mutual consent was not legally valid in France. ${ }^{21}$ The court agreed with him, reasoning on the basis of the distributive analysis that, since Lydia was a French national and had been married in France, French law should have been applied. However, French law did not recognize mutual consent as a ground for divorce, with the result that the Equadorian divorce had no legal effect in France.

The Cour d'appel of Rabat in turn reversed that decision, ruling that the law applicable to spouses of different nationality should be either (1) the husband's national law; (2) the law of the common domicile, or (3) the law of the forum in which the action is brought. While it did not choose between them because they all recognized mutual consent, the court did overrule explicitly the distributive analysis of the Ferrari court upon which the Casablanca tribunal had relied, emphasizing the need to achieve national and international uniformity in personal status matters:

[T] he distributive application of the national law of each spouse should be formally disregarded as arbitrary and juridically impossible [to apply] in determining the effects of marriage and the sanction of the obligations of marriage that divorce constitutes since the rights of one spouse have as a counterpart the obligations of the other; that there exists in divorce matters a veritable indivisibility; that it is important to both the national and international interest, that two spouses

18. Id.

19. E.g., Francescakis, "Le divorce d'époux de nationalité différente," $43 \mathrm{Rev}$. Crit. Dr. Int'l Priv. 325, 327, 327 n. 2 (1954).

20. 38 Rev. Crit. Dr. Int'l Priv. 107 (1949) [Cr. d'appel de Rabat 30 Nov. 1948]. See also Batiffol, Note, id. at 109-12; "Recognition in France of Foreign Decrees Divorcing Spouses of Different Nationality," $4 \mathrm{Am}$. J. Comp. L. 574 (1955); Lagarde, "Destinées de l'arrêt Rivière," 98 J. Dr. Int'l-Clunet 241 (1971).

21. 38 Rev. Crit. Dr. Int'l Priv., supra n. 20 at 107-08. 
either be not married or divorced but not at the same time one and the other.

But the Cour de Cassation had the last word: it upheld the ruling of the Rabat court by giving reciprocal effect to Art. 3 Code Civil. ${ }^{22}$ It declared that, in cases involving personal status, the sole fact that one of the parties is a French national is not sufficient in all cases to render French law obligatory. The merits of a divorce proceeding between a French and a foreign national, both of whom were domiciled in the same foreign jurisdiction, were "governed by the law of the domicile, which was, in addition, identical to the husband's national law and the law of the forum." The "in addition" clause created some uncertainty in regard to the priority that was to be established between the three possible sources of governing law, ${ }^{23}$ but a few years later the court clarified this ambiguity.

In Dame Lewandowski c. Lewandowski, ${ }^{24}$ a Polish national, domiciled in France, filed an action before a French tribunal for divorce from his French wife (who was also domiciled in France). The lower court granted the divorce on account of injures graves (moral cruelty), reasoning that the husband's national law recognized that ground for divorce. The Cour de Cassation reversed, holding that French law should have been applied. It thereby established as a clear and mistakable choice of law rule that the law of the common domicile governed the merits of an international divorce proceeding in the absence of common nationality between the spouses. ${ }^{25}$ The judicial doctrine elaborated in these cases, however, left one problem unresolved: viz., which law to apply in the event the spouses had neither a common nationality nor a common domicile?

The court addressed that problem in Tarwid c. dame Wirtensohn ${ }^{26}$ where a Polish national had married a French national in London in 1947. Although the couple remained in England after their marriage, when they separated the wife returned to France and her husband remained in England. In February 1955, she filed for divorce in France on the basis of Art. 14 Code Civil, but her husband countered that English, not French, law should be applied since his legal domicile was English. The Cour de Cassation however decided in favor of the forum law:

[T] he divorce of spouses of different nationality is governed by the law of the common domicile if they are both integrated into the local milieu by having an effective residence in the same country; if they live separately in different countries, the divorce proceeding is governed by the law of the forum which has jurisdiction to hear the matter.

22. Rivière c. Roumiantzeff, 42 Rev. Crit. Dr. Int'l Priv. 412 (1953) [Cr. de

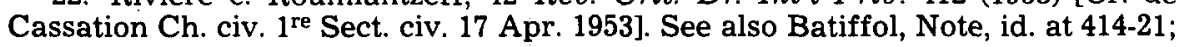
Lagarde, supra n. 20.

23. See Batiffol, supra $n .22$ at 420 .

24. 44 Rev. Crit. Dr. Int'l Priv. 320 (1955) [Cr. de Cassation Ch. civ. Sect. civ. 15 Mar. 1955]. See also Batiffol, Note, id. at 322-25.

25. See Batiffol, supra n. 24 at 323.

26. 50 Rev. Crit. Dr. Int'l Priv. 547 (1961) [Cr de Cassation Ch. civ. $1^{\text {re }}$ Sect. 15 May 1961]. See also Batiffol, Note, id. at 548-53. 
The doctrine expressed in these cases established a comprehensive set of rules by which the courts could deal with the choice of law issues in international divorce actions. It clearly established for example that although a French national was a party to the action, French law relating to personal status did not apply automatically-nor did the husband's national law. Rather, for the sake of reciprocity and to preserve judicial equality between the spouses, the courts would, in the absence of a common nationality, designate, in order of preference, either the law of the common domicile or the law of the forum. This pattern has now been replaced by the new Art. 310 Code Civil.

\section{The New Art. 310 Code CiviL}

The new Art. 310 was enacted as part of the law of 11 July $1975^{27}$ which substantially modified existing French divorce law. The article contains three choice of law rules which determine the applicability of French law in international divorce actions. The article reads:

The divorce and separation [of spouses] is governed by French law:

-when one and the other spouse are of French nationality;

-when the spouses have, one and the other, their domicile on

French territory;

-when no foreign law recognizes itself as governing, once the French courts have jurisdiction to hear a divorce or separation action. ${ }^{28}$

The language of Art. 310 has generated considerable scholarly criticism. ${ }^{29}$ The chief feature of the choice of law rules contained in the article, in contrast to the previous judicial rules, is their "unilateralist" character. That is to say, instead of promulgating rules indicating when both national and foreign law are to be applied, the legislature contented itself with enumerating only those instances in which French law is mandatory. In the opinion of one commentator, although the legislature apparently intended to codify previously established conflicts doctrine, the unilateralist character of the Art. 310 choice of law rules in fact represents a complete depature from the jurisprudence elaborated in Rivière and refined by its progeny.

27. Law No. 75-618 of 11 July 1975, (1975) J.O. 7178, Dalloz, Législation at 254 (1975). For an analysis of the new law, see e.g. Glendon "The French Divorce Reform Law of 1976," 24 Am. J. Com. L. 199 (1976); Lasok, "The Reform of French Divorce Law," 51 Tul. L. Rev. 259 (1977).

28. "Le divorce et la séparation de corps sont régis par la loi française:

"-lorsque l'un et l'autre époux sont de nationalité française;

"-lorsque les époux ont, l'un et l'autre, leur domicile sur le territoire français;

"-lorsque aucune loi étrangère ne se reconnaît compétence, alors que les tribunaux français sont compétents pour connaître du divorce ou de la séparation de corps."

29. Cornec, "Le Nouveau Divorce International," 2 Gaz. Pal. Doctrine at 612; Foyer, "Tournant et Retour aux Sources en Droit International Privé?", La Semaine Juridique JCP Doctrine No. 2762 (18 Feb. 1976); Francescakis, supra n. 5; Simon-Depitre, "Le nouve article 310 du Code civil," $103 \mathrm{~J}$. Dr. Int'l-Clunet 823 (1976); see also Mayer, Droit Int'l Privé 412-17 (1977). One scholar has characterized the article as the "product of too little thought" and "[an] improvisation": Francescakis, supra n. 5 at 554. 


\section{Rule 1}

The first provision of Art. 310 is the most traditional and least problematic of the three rules. It provides that French law will govern when both spouses are French nationals, following in effect the basic orientation of Art. 3 Code Civil, which applies French law to the personal status of French nationals. Like Art. 3, this rule can be applied reciprocally so that international divorce actions would be governed by the national (possibly foreign) law common to both spouses. ${ }^{30}$ But once the provision is interpreted bilaterally, there will be no choice of law rule for spouses with different nationalities. According to one scholar, ${ }^{31}$ this lacuna stems from the original unilateral character of the provision itself.

\section{Rule 2}

The second provision of Art. 310 represents a partial innovation. According to its proponents, this second choice of law rule was intended to deal with immigrant spouses who seek a divorce in France. ${ }^{32}$ In their view, the doctrine of the Rivere case and its progeny misunderstood the needs and desires of the numerous immigrant families in France, since it denied to them the law of their new common domicile if they shared the same foreign citizenship. Although the first rule of Art. 310 requires application of French law when an action involves two French nationals notwithstanding the fact that they may have a common foreign domicile, the second rule establishes a different standard to deal with foreign nationals living on French soil. The justification for this separate treatment centers upon the notion of l'esprit de retour, the desire of foreign nationals to return eventually to their mother country. ${ }^{33}$ Although they offer no statistical support, its proponents argue that French nationals residing abroad retain a desire to return to France, while the foreign nationals in France have lost any wish to reintegrate themselves into their country of origin. Accordingly, to apply any other than French law would constitute a misreading of existing reality: the national law of these foreign immigrants reflects principles and mores alien to their present environment. Moreover, ascertaining their national law would place an onus upon the courts, besides involving the risk of having it applied inaccurately. ${ }^{34}$

While this reasoning is well-intentioned, albeit smacking of an outmoded and extreme form of paternalism, it nonetheless makes for unequal treatment which is buttressed by pure conjecture at best. Moreover, it fails to account for the situation in which the dissolution of marriage would mean for at least one of the immigrant spouses a return to the country of national origin. In that event, would the French divorce be recognized by the national courts of the foreign country? Would the French courts have applied the choice of law rules required by the law of the foreign country? Would the ground upon which

30. See Francescakis, supra n. 5 at $\mathbf{5 6 1 .}$

31. See id. Accord, Simon-Depitre, supra n. 29 at 826-27.

32. See Foyer, supra n. 29, at No. 2762.

33. Id.

34. Id. 
divorce was granted be recognized by the foreign law? Indeed, do the laws of the country of origin recognize divorce at all?

The weakness of the reasoning is compounded by the assertion that foreign law is not only difficult to ascertain, but also likely to be misapplied. As the discussion immediately below will illustrate, those misgivings apparently were completely forgotten in relation to the third provision of Art. 310, which obliges French courts, at least in theory, to engage in the task of determining and reconciling the choice of law rules possibly of several different countries. As one prominent French internationalist has noted, ${ }^{35}$ the second provision of Art. 310 may well lead many foreign countries, concerned about the inapplicability of their own laws, to negotiate bilateral conventions on personal status with France.

Finally, the concept of common domicile contained in the second rule could have unanticipated consequences. While the spouses to a divorce action must be both domiciled in France in order for French law to apply, they need not be living together in order to satisfy the requirements of common domicile. Depending upon what precise legal definition the courts eventually affix to the term, the application of the concept of common domicile conceivably could have the consequence of transforming France, as it were, into a European Reno. ${ }^{36}$ Foreigners whose national law on divorce is particularly restrictive would be encouraged to establish some sort of domicile in France and to seek a divorce under the second rule of Art. 310. In such cases, it is hoped that the courts will engage in an assiduous scrutiny of the record to determine whether the parties have actually established bona fide domiciles in France. Such an inquiry will probably prove as cumbersome as the ascertainment and application of foreign law. Moreover, like the first provision of Art. 310, the second could also be given reciprocal effect, i.e., subjecting a divorce between spouses of the same foreign domicile to the law of that common domicile. ${ }^{37}$ As noted earlier, the bilateral interpretation of both these rules, while promoting reciprocity between national legal systems, would leave rather significant lacunae in the French choice of law rules: thus Art. 310 would not cover spouses of neither common nationality nor common domicile. ${ }^{38}$

\section{Rule 3}

The third rule of Art. 310 is the most innovative of the three. Although intended, ${ }^{39}$ at least in part, to support the Rivière principle that divorce, regardless of its international character, should be governed by one national law only, it marks a complete departure from former choice of law principles. ${ }^{40}$ Due to its negative formulation, the courts cannot give the provision reciprocal effect. ${ }^{41}$ Consequently, when a French court assumes jurisdiction in a suit between, e.g., a French and

35. See Francescakis, supra n. 5 at 560 .

36. Id.

37. See Francescakis, supra n. 5 at 561 .

38. Id.

39. See Foyer, supra n. 29, at No. 2762.

40. See e.g. Simon-Depitre, supra n. 29 at 824 .

41. See Francescakis, supra n. 5 at 563 . 
a Spanish national, both of whom are domiciled in their respective countries, it will apply foreign law whenever the choice of law rules of the foreign country designate its law as governing. ${ }^{42}$ Although it is unclear whether the parties bear the burden of raising the applicability of foreign law or the court may raise it sua sponte, once the issue is before the court, it must ascertain and apply not only the foreign conflicts principles and reconcile them with their French counterparts, but also eventually gain an awareness of the substance of the foreign law and apply it correctly. ${ }^{43}$ In some cases involving spouses who are not domiciled in France but in two different countries other than those of their national origin, several foreign laws may be applicable. In these circumstances, it will be incumbent upon the French courts to devise judicial criteria for choosing between the various foreign laws and conflicts principles. Hence a French citizen, whose spouse is a foreign national and living abroad, may well be subject to foreign law, despite the fact that he brought the action before a French court. Divorce may even be impossible altogether, e.g. between a French and a Spanish national who are domiciled in their respective countries. Presumably, according to the new French rules, Spanish law (if its conflicts principles designate it as governing) would apply in such a case. Yet Spanish law prohibits divorce. One possible solution to this impasse might be for the French courts to declare the application of such a foreign law to be against French public policy (l'ordre public). How the courts will deal with an applicable foreign law, which, although not entirely prohibiting divorce, is more restrictive than French law, also remains to be seen. In any event, it is hoped that the courts will not treat the choice of law rules contained in Art. 310 as an exhaustive enumeration of the possible solutions to the multifarious conflicts problems that can arise in the context of international divorce actions. ${ }^{44}$

The new rules also raise considerable problems in the related area of enforcing foreign divorces in France. ${ }^{45}$ Although foreign divorces are recognized in France without any judicial action, the granting of an exequatur becomes indispensable if the decree is introduced into a French jurisdiction for purposes of enforcement. In order to be granted an exequatur, the foreign judgment must satisfy five conditions, one of which requires that the foreign court must have applied the law designated by the French choice of law rules. ${ }^{46}$ In the case of two foreign nationals of different nationalities who were domiciled in France but were divorced in one of the countries of their national origin according to its law, the French courts, under the provisions of Art. 310, would be

42. As one commentator has noted, this new choice of law rule would also raise issues under the renvoi doctrine. See Ecolivet-Herzog, "The New French Divorce Law," 11 Int'l Lawyer 483, 498 (1977).

43. See e.g. Cornec, supra n. 29 at $613-14$.

44. See Francescakis, supra n. 5 at 563 .

45. See e.g. Cornec, supra n. 29 at 614.

46. These five conditions were laid down in the celebrated Munzer case, $91 \mathrm{~J}$. Dr. Int'l-Clunet 302 (1964) [Cr. de Cassation Ch. civ. $1^{\text {re }}$ Sect. civ. 7 Jan. 1964]. See also Goldman, Note, id. at 304-09; Nadelmann, "French Courts Recognize Foreign Money Judgments: One Down and More to Go," 13 Am. J. Comp. L. 72 (1964); generally Herzog, Civil Procedure in France ch. 14 (1967). 
obliged to deny the request for exequatur. The spouse seeking to have the judgment enforced in France would be left without any judicial remedy, except to initiate a second divorce proceeding - this time in France. Conversely, as mentioned previously, ${ }^{47}$ the possible laxity of the domiciliary requirement of Art. 310 would render the recognition and enforcement of French divorce judgments abroad more difficult.

These latent doctrinal and practical problems will, of course, surface only in future litigation. Their effective resolution will depend, almost exclusively, upon judicial ingenuity and imagination. Although Art. 310 only became effective on 1 January 1976, the courts already have begun the task of implementing and interpreting it. The relatively few decisions already confirm at least some of the apprehensions raised in the foregoing analysis.

\section{RECENT DECISIONS}

In Dame Lofiego c. Lofiego ${ }^{48}$ two Brazilian nationals domiciled in Brazil were granted a judicial separation on the ground of mutual consent by a Sao Paulo tribunal. The wife subsequently established a domicile in Paris and brought an action before a Paris court, seeking to convert the Brazilian separation into a French divorce decree. The husband, although not present at the proceeding nor personally served with notice, maintained a residence in France; notice was served by delivering a copy of the summons at the city hall of his alleged residence in France.

Ruling on the jurisdictional issues, the court declared that a foreign separation can be converted into a French divorce provided the foreign decree was based on grounds recognized as divorce grounds by the law governing the conversion action. The court went on to state that, even in the absence of an explicit request, it must determine whether the foreign judgment conformed to the requirements of international procedural and substantive regularity. It ruled that the Sao Paulo court had jurisdiction, had conducted the proceeding according to accepted procedure, and had applied the law designated as the governing law by French conflicts rules then in force-namely, Brazilian law by virtue of the common nationality of the spouses. Since the decision did not violate French public policy, the judgment was enforceable in France.

Regarding the request for conversion, the court noted that both spouses were now domiciled in France. Since the request had been submitted to the court after the new conflicts rules came into force, Art. 310 applied. According to its second rule and because both spouses were domiciled in France, French law was therefore the governing law despite the spouses' common Brazilian nationality.

Still, the court denied the conversion on the ground that Art. 307 Code Civil $^{49}$ requires conversion of a separation by mutual consent to

47. See text supra at $n .35$.

48. 66 Rev. Crit. Dr. Int'l Priv. 335 (1977) ['Trib. grde Instance de Paris $1^{\text {re }}$ Ch. 20 Jan. 1977]. See also Gaudemet-Tallon, Note, id. at 337-44.

49. "In all cases involving separation, the latter can be converted into a divorce by the request of both spouses. When the separation was granted on the ground of 
be requested by both parties. Art. 307 applied not only as a procedural rule of the forum, but also on substantive grounds: to implement the guarantee of Art. $232^{50}$ by which the legislature intended to assure a spouse that his acceptance of a separation by mutual consent would not result in a unilateral divorce.

The court's interpretation of Art. 310 does indeed confirm the misgivings that many French scholars expressed about the future application of the new choice of law rules. While the record established that both spouses were presently domiciled in France, the court gave precious little scrutiny to the questionable character of the husband's French domicile. Apparently, it simply accepted the documentation submitted to it which established that $\mathrm{Mr}$. Lofiego had registered as a resident of Bourg-la-Reine. In light of the fact that Brazilian law does not recognize divorce and in view of the husband's conspicuous absence from his French residence and his failure even to retain counsel, one would suspect either collusion on the part of the spouses to obtain a divorce in spite of the prohibition of Brazilian law or unilateral fraud on the part of the plaintiff.

Yet, there is no hint in the official decision that the court suspected either of these two possibilities. The court simply confined itself to a superficial scrutiny of the record and applied rather literally the second rule of Art. 310. Nor did the court give reciprocal effect to the first rule of Art. 310. Under the old conflicts rules, it would have applied the national law common to both spouses, viz. Brazilian law. Presumably, the request for conversion would have been denied on the ground that Brazilian law did not then recognize divorce. Although the court achieved the same result by applying another provision of French law, its distinctly uncritical application of the common domicile concept bespeaks a laxity that could render French jurisdictions a haven for foreign nationals seeking to escape the rigors of their own national divorce laws. In any event, the court could have applied the third rule of Art. 310. Ascertaining and applying Brazilian conflicts rules and substantive divorce provisions did not present, at first blush at least, insurmountable difficulties. Had the court deemed the relevant Brazilian laws to be fundamentally repugnant, it could have declared them contrary to French ordre public and applied French law on that more legitimate basis.

The other recent international divorce cases have not dealt directly with the interpretation of the three new choice of law rules, but affirmed the traditional principle that, under Art. 14 and 15 Code Civil, ${ }^{51}$

the spouses' mutual consent, it cannot be converted into a divorce except by a new request by both spouses." The French text of the article reads: "Dans tous les cas de séparation de corps, celle-ci peut être convertie en divorce par demande conjointe. Quand la séparation de corps a été prononcée sur demande conjointe, elle ne peut être convertie en divorce que par une nouvelle demande conjointe."

50. "The judge will grant a divorce if he is convinced that the desire of each spouse [to obtain a divorce] is real and that each of them has freely given his agreement. . . ."The French text of art. 232 reads: "Le juge prononce le divorce s'il a acquis la conviction que la volonté de chacun des époux est réelle et que chacun d'eux a donné librement son accord. . . ."

51. See text supra at and accompanying n. 7 and 8 . 
the French courts have jurisdiction over an action brought by a French national on the exclusive basis of his nationality, notwithstanding the fact that foreign law may govern the substantive merits.

In Dame $L$. . . c. son mari, ${ }^{52}$ both spouses had been domiciled in Rome for several years. They lived there together with their child and taught school. The wife was a native of Paris, had been married there, and had given birth to their child in the French capital. Upon returning from Italy, she filed for divorce in Paris. At this initial stage of the proceeding, the case was before a family law judge whose official duties consist in attempting a reconciliation of the spouses before and during the court proceeding, his judicial competence being limited to matters relating to the jurisdiction of the court. ${ }^{53}$ The husband contested the applicability of French law, as the case did not fit any of the three hypothetical situations adumbrated by Art. 310 . He further contended that, since the couple was domiciled in Italy, Italian law would be applicable.

The Tribunal de grande instance of Paris however ruled that the conflicts issue was without the family law judge's competence and irrelevant to a determination of whether the French courts had jurisdiction to hear the action. The court declared that, in French private international law, Art. 14 and 15 Code Civil were still in effect so that a French national could sue for divorce in France although the other spouse was a foreign national and resided abroad-providing that choice did not smack of fraud or represent an abuse of procedure. Ultimately, it was up to the petitional court to determine whether French or Italian law governed on the merits.

$G$.... c. sa femme $e^{54}$ was an almost identical case from both a procedural and substantive point of view. It nevertheless deserves mention for the sake of completeness and the court's dicta. Mr. de G . . ., a French national, lived with his wife, apparently a U.S. citizen, and children for many years in Kansas City. In 1968, he returned to France and established a domicile in Paris. His wife remained in the U.S. with their two children. Mr. de G . . . filed a divorce action before a Paris court, asserting that French law should govern the proceeding by virtue of his French domicile; his wife contested the French jurisdiction since her residence was in the U.S. and further alleged that French law was inapplicable to the merits, since the case did not fall into any of the categories of Art. 310 .

As to the court's jurisdiction, the Tribunal de grande instance of Paris held that the Decree of 5 December 1975, (which designates "the tribunal of the place where the family resides") ${ }^{55}$ had effect only in French domestic law and did not abrogate Art. 14 and 15 Code Civil. Accordingly, under Art. 14, a French national could sue for divorce in

52. $96: 2$ Gaz. Pal. Jurisprudence at 717 (1976) [Trib. grde Instance de Paris 12 Jul. 1976]

53. See generally Cornec, supra n. 29 at 613 ; Groslière, "Le juge aux affaires matrimoniales," Dalloz Chronique at 73 (1976).

54. Supra n. 52 at 723 (1976) [Trib. grde Instance de Paris 3 May 1976].

55. Décret No. 75-1124, art. 5, in Code Civil at 163, 164 (1976-77). 
France even if the other spouse was of foreign nationality and resided abroad. Although the issue of the governing law was not strictly before the court, it asserted by way of dictum that at least two of the Art. 310 provisions might apply to the instant case: (1) in the event that Mrs. de G . . . acquired French nationality upon her marriage, the first rule of Art. 310 would require the court to apply French law; and (2) in the pleadings submitted thus far before the court, Mrs. de G . . . claimed that the law of Colorado ${ }^{56}$ did not state whether it applied to the merits of a divorce proceeding in a foreign jurisdiction against one of its residents. On that basis, the court opined that the third rule of Art. 310 would require the application of French law since the defendant admitted the inapplicability of her national (i.e., state) law.

Suffice it to state that the court's dicta were extremely conjectural and, perhaps, imbued with some misplaced nationalism. On the one hand, it was unlikely that the wife had assumed French citizenship upon her marriage, since the couple resided in the U.S. until their separation. On the other hand, a note submitted in preliminary pleadings should not suffice to determine the complex and delicate question of which law should govern the merits of the proceeding. This is especially true in light of the lack of consensus and controversy that the new conflicts rules have generated among French legal scholars and in view of the fact that other considerations may impinge upon the ultimate application of Art. 310 in the instant case.

\section{CONCLUSION}

The choice of law issues confronted by a French court in a contemporary international divorce action have not changed markedly in character since the Ferrari decision; the jurisprudence of the courts, however, has undergone two radical transformations. First, in an effort to establish a more acceptable and less problematic judicial doctrine than that advanced in Ferrari, the French courts, in Rivière and subsequent cases, devised a set of choice of law rules which were tailor-made to deal with the conflicts problems arising in international divorce cases. These rules were not only comprehensive, but also cogently articulated, besides promoting the principle of reciprocity. Although not accounting for all the possible subtleties in a myriad of hypothetical fact patterns, these rules nonetheless provided satisfactory answers to classical questions. As such, they represented a not inconsiderable achievement in judicial creativity.

Second, the choice of law jurisprudence was changed only recently, but this time by legislative decree. In view of the doctrinal and practical viability of the previous rules, it is regrettable that the French Parliament decided to intervene at all-all the more because it chose to transform the entire orientation and substance of these rules with a hasty and ill-conceived enactment. Rather than codify or supplement existing law, the new statute revolutionized: tearing the fabric of doctrinal consensus in an already perplexing area and erecting obstacles to the future elaboration of a cohesive doctrinal framework. Although the

56. Colorado being her present domicile. 
initial interpretations of the new provisions do not herald a new surge of creativity and analytical clarity among the French courts, it is hoped that they will respond to the negative challenge presented by Art. 310 in much the same vein as did their predecessors in the Rivière-Tarwid jurisprudence. 